препятствия в области выводных каналов. В отнопении полового канала у женщин дело идет не о грубых изменениях, но о таких нарупенилх, юосторые ничем себя не проявляют, однако, действуя долгое время, приводят к раздражению клеток. Задержгу секрега автор считает и прелрасполагапцей к раковому перерождению серозных кистаденом и эндометриом яичнига. На основании больпого матердала G. считает именно стриктуру первичным изменениен. Отспда в целях профилактики он реклмендует самую больпую тщательность при производстве операцив, в особенности пластических.

A. Тинояеев.

534 Темение рака матии ачетоном и радием. По G ell ho r n'y (Zentr. f. G., 1927 , № 49) радий может быть применяем не во всех случаях рака матки, и для этих случаев (. предлагает лечение ацетоном. Эти случап: 1) больные с резкой кахексией, поторые не в состоннии перенести нагрузки организма продуктами распада при лечении радием; 2) больные с поражением мочевого пузыря и прямой ники; 3) случаи с плоскостным распространенпем palia по стенкам влагалица. Технша леченил ацетоном состоит в следующем: раковый очаг выскабливается, больной придается Trendele n b u g'овское положение, и в рукав сй вводится трубчатое зеркало, которое наполняется 1-2 столовыми ложками чистого ацетона. Через 10 минут ацетон осторожно удаляется и заменяется новой порцией, которая удаляется через 20 мин. Такое лечение повторлется втечение первых двух недель ежедневно, а затем через 2 дня. Наружные половые части не должны приходить в сопригосновение с ацетоном. Тампонады не применяется. Результатом лечения в короткое время являются уплотнение ткани и эпителиализация ракового кратера.

\title{
ж) Jеduampuя.
}

A. Tunogeeв.

535. Ацентонэмия у демей. K r a b b e l (Zentr. f. Chir., 1928, № 13) наблюдал случай сильной рвоты с неопределенными болями в животе у 6-летнего ребенка, сына врача. Картина болезни очень походила на острый приступ аппендицита, но смущал сильный зашах ацетона в выдыхаемом больным воздухе. Исследование мочи обнаружило также наличность в ней ацетона. После двукратного приема инсулина по 5 единиц больной быстро стал поправляться. Причина этого страдания неизвестна; возможно, здесь играют роль гонституциональные моменты.

$$
\text { II. Іиммхес. }
$$

536. Прогностика заооолеваний помек у детей. На основании больпого, хорошо прослеженного клинического материала $R$ os en molle r (Arch. f. Kinderheil., 1928, Bd. 84) приходит ж заключению. что прогностика почечных заболеваний в детском возрасте гораздо благоприятнее, чем у взрослых, так гаґ замена заболевщих почечных әлементов новообразованными илетками происходит здесь тораздо легче.

$P$.

537. Эфедрин при кокілоие. A n d e r s o n и $\mathrm{H}$ om an (Am. journ. of med. sc., 1927, v. 174) получили очень хоропие результаты в 20 случаях лечения поклюпа эфедрином. Последний давалсл в водном растворе per os-y детей старшө 1 года в дозе 0,016, моложе 1 года-0,008, в 6 случаях только по вечерам, в остальных - и утром, и вечером. Полное устранение сүдорожного кашля и рвоты наступило в 18 случаях, причем, впрочем, у всех больных оставался еще небольшой капель. Каких-либо токсических явлений средство это не вызывало. $B . C$.

\section{3) Ұrebponamorozus u nсихиатрия.}

538. ІІрививки четверодневной оолотной лихорсдки при метасифилисе. На основании 7-летних наблюдений W. K i s ch b u m находит (Münch. med. W., 1928, № 11), что результаты прививок m. quartanae ничуть не хуже, чем трехдневной лихорадки, и все лечение, кроме того, нежнее, почему и рекомендуется особенно у слабых больных.

C. $\Gamma$.

539. Деойной алпетоз после воздуиной контузии. М. Е. С об о л ь (Совр. Психоневр., 1927, № 10) приводит интересный случай, где в результате воздушной контузии провзопло, по мнению автора, двустороннее кровоизлияние в области верхних отделов c. striati и отчасти pallidi. Этой локализацией автор и объясняет наб́людавпуюся здесь клиническую картину: двойной атетоз, преимущественно в мускулатуре лица и в дистальных отделах верхних конечностей, небольпую торзию и легкие парамидные симптомы с одной стороны. $I$. Первулин. 